\title{
Production of Virgin Coconut Oil Using Fermentation Method Extraction with Ragi Tempe
}

\author{
Novian Wely Asmoro \\ Universitas Veteran Bangun Nusantara \\ Sukoharjo, Indonesia \\ novianwelyasmoro@gmail.com \\ Afriyanti \\ Universitas Veteran Bangun Nusantara \\ Sukoharjo, Indonesia \\ afriyantistp@gmail.com
}

\author{
Retno Widyastuti \\ Universitas Veteran Bangun Nusantara \\ Sukoharjo, Indonesia \\ widyaastuti r@yahoo.com \\ Junius Ndrudu \\ Universitas Veteran Bangun Nusantara \\ Sukoharjo, Indonesia \\ ndrudu@gmail.com
}

\begin{abstract}
Virgin Coconut Oil (VCO) is a pure oil obtained from the extraction process of coconut meat. Having a composition of $65 \%$ of the constituents of fatty acids in coconut meat is medium chain saturated fatty acids (MCFAs). The development of the current method of processing VCO is directed to methods that do not involve the heating process so that VCO can be obtained with the best quality. The study aims to study the effect of comparison of the cold method VCO extraction process on the yield of VCO produced. The experimental design used in this study was a completely randomized design (CRD) with two treatment factors, namely the variation of Ragi tempe concentration used with 4 treatment levels, K1 = Control, K2 $=2 \mathrm{~g}, \mathrm{~K} 3=4 \mathrm{~g}, \mathrm{~K} 4=6 \mathrm{~g}$ and the length of time fermentation process $(T)$ with 2 levels of treatment, $T 1=24$ hours, and $T 2$ $=48$ hours. Characteristic testing of VCO includes specific gravity, moisture content, and FFA value (free fatty acids). Statistical data analysis using SPSS 17 software with ANOVA method then continued with Duncan's Multiple Range Test (DMRT) if there are significant differences between treatments. The results showed that the VCO yield obtained ranged from $21.56 \%-24.29 \%$, the average FFA value was $0.50 \%$, the average water content was $0.49 \%$ and the average density was $0.87 \mathrm{~g} / \mathrm{ml}$.
\end{abstract}

Keywords-coconut, fermentation, ragi tempe, $\mathrm{VCO}$

\section{INTRODUCTION}

Coconut (Cocos nucifera) is one of the plantation commodities that is widely cultivated in the Tropical Country including in Indonesia. Coconut received the nickname tree of life because of its vast utilization. Coconut in Indonesia has been widely used as a food product among others: beverage products, biscuits, nata de coco, instant coconut milk and mainly as a source of the largest vegetable oil after palm oil [1]. Coconut oil is processed through the process of making copra by drying the coconut meat. Copra has an oil content of $65 \%-75 \%$ with water content below $10 \%$. The oil extraction process in copra uses pressing and heating techniques [2]. Manufacture of household-scale palm oil are also some people still do it by way of warming up of coconut milk to the remaining oil and dregs (blondo). The process causes the quality of oil produced poor (rancid quickly) and relatively low power shelf [3].

The development of virgin coconut oil (VCO) is one produced from coconuts are widely known by the public. The pure oil obtained from the extraction process of coconut meat will produce naturally identical content with the composition of fatty acids in coconut meat. Coconut meat has a major fatty acid composition is a fatty acid lauric acid C 12: 0 (49\%), and fatty acids of medium chain so that a total of approximately $65 \%$ constituent fatty acids in coconut meat is medium chain saturated fatty acids (MCFAs) [2].

The process of making the VCO can be made through three methods are heating, fermentation, and inducement. The principle of making VCO by the heating method is that the cream obtained from coconut milk is heated to a certain temperature so that the oil is separated from the cream and the water evaporates due to heating. Making VCO by fermentation method is done by adding microorganisms to help the process of separating oil and protein components. The fermentation process will be the formation of three layers, namely the top layer in the form of pure oil, the middle layer in the form of blondo (protein), and the bottom layer is water. The fishing method, the principle of manufacture with the fishing method is the conversion of the oil-water emulsion. Feed oil is used to attract oil in the cream which is still bound to protein and water [1], [3]-[8]

The development of the current method of processing $\mathrm{VCO}$ is directed to methods that do not involve the heating process so that VCO can be obtained with the best quality. Without involving a heating process will not lead to changes in the composition of fatty acids in the VCO. So that the composition of fatty acids in $\mathrm{VCO}$ resembles the composition of fatty acids in coconut meat which is dominated by MCFAs content. MFCAs are the content of saturated fatty acids consisting of $49 \%$ lauric acid and 7-10\% capric acid. The existence MCFAs on coconut oil has health benefits that have been studied include ease digested in the body, has anti-bacterial 
activity, the stability of the cholesterol in the body, and potential prevention of cardiovascular disease and diabetes mellitus [2], [9], [10].

The VCO extraction method that is used will cause changes in the composition of fatty acids so as to reduce quality. Quality is a parameter to determine the quality of a product. Especially VCO has a quality standard as a reference for determining the quality. The VCO quality standards used are the standard of ISO and APCC (Asian and Pacific Coconut Community). Several extraction methods have been studied VCO generates physical and chemical parameters are different for each method. Among other uses habitation and inducement method in coconut milk so that separate oil itself. The method of adding papain enzymes can produce $49 \%$ yield and quality according to SNI. VCO extraction by the centrifugation method yields of $52.23 \%$, it's just that the weakness of this method is difficult to be applied on a small industrial/household scale. Extraction VCO by fermentation methods using Saccharomyces cerevisiae and some types of yeast [5], [11], [12].

One way to get VCO with an easy method and to produce physical and chemical characteristics in accordance with SNI and APCC standards. Fermentation method is an alternative that can be used in the production of VCO. Fermentation methods classified as a cold method that is expected to produce a VCO with a good yield and quality. The purpose of this research study the effect of fermentation time and inoculum concentration on the physical and chemical characterization of the VCO.

\section{METHOD}

This research was conducted in several stages: the first stage of VCO extraction of coconut meat using fermentation methods. The second phase, the physical and chemical analysis of the character of the VCO.

A. The VCO yield

VCO yield is determined based on the amount of VCO that can be taken from coconut meat compared to the total weight of the coconut meat, expressed in percentages $(\%)$.

B. Water Content

Analysis of water content using thermogravimetry method by calculating the difference in weight of water can be evaporated from the material. The water content expressed as a percentage (\%) [13].

C. Specific Gravity

Analysis using the tool pycnometer specific gravity, density calculated from the ratio of the mass of material to the volume of material. Density expressed in grams $/ \mathrm{ml}$.

\section{FFA Content (Free Fatty Acid)}

FFA showed the free fatty acids present in the oil, free fatty acids calculated based on the results of titration of $\mathrm{NaOH}$-bound free fatty acids in the oil.
The experimental design used in this study was a completely randomized design (CRD) with two treatment factors, namely the concentration of yeast tempe in $20 \mathrm{ml}$ of solvent used with 4 treatment levels, $\mathrm{K} 1=0, \mathrm{~K} 2=2 \mathrm{~g}$, $\mathrm{K} 3=4 \mathrm{~g}, \mathrm{~K} 4=6 \mathrm{~g}$ and fermentation process time $(\mathrm{T})$ with 2 levels of treatment, $\mathrm{T} 1=24$ hours, and $\mathrm{T} 2=48$ hours. Each treatment was repeated three times. Thus obtained experimental unit 4 × 2 × $3=24$ experimental units. Data obtained from the physical and chemical analysis calculated statistically using SPSS 17 software by using ANOVA followed by a test of Duncan's Multiple Range Test (DMRT) if there are significant differences among the treatments. Presentation of charts and tables using Microsoft Excel 2010 software.

\section{RESULTS AND DISCUSSION}

\section{A. Yield VCO}

The yield of the VCO from an extract of coconut milk can be seen in Figure 1. The results of the VCO yield calculation factors varying concentrations of $0 \%, 2 \%, 4 \%$, $6 \%$ and 2 variations of long fermentation time is 24 hours and 48 hours resulted in an average yield of $21,56 \%$ for 24 hours fermentation time and $24.29 \%$ for 48 hours fermentation time. Statistical analysis showed the yield of VCO results are influenced by the old variable tempeh fermentation and yeast concentration used ( $\mathrm{F}$ count: 1,587). Overall fermentation time and concentration factor affecting the yield of VCO produced $(\alpha<0.05)$, but each factor separately no significant effect on the yield value. The combination of both factors fermentation time and concentration can have a significant effect on the yield of the resulting VCO. The use of yeast concentration of $6 \%$ and the duration of fermentation 48 hours give the highest yield is $31.47 \%$.

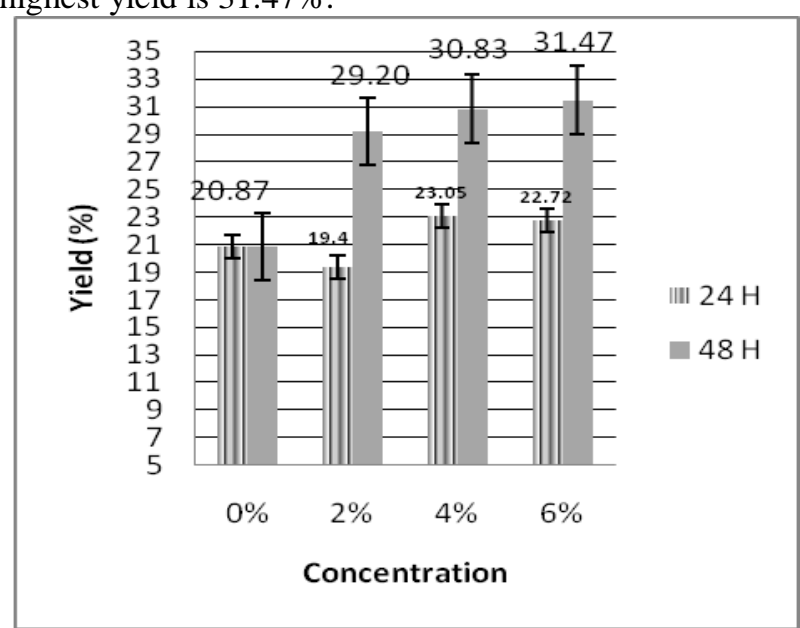

Fig 1. Graph Yield of VCO

The longer the fermentation process takes place, the more oil components can be released from the protein matrix in the coconut emulsion, which is between water, protein, and oil. Tempe yeast which consists of microorganism culture, especially Rhizopus oryzae fungi, $R$. oligosphorus or $R$. stolonifer has protease enzyme activity. Protease enzymes have the ability to break down proteins in the components of coconut milk emulsion so as to encourage the separation of oil, protein and water fractions. In some studies conducted by [14][8][11] using 
several other methods such as fermentation and the use of enzymes can encourage the breakdown of emulsions in coconut milk to produce VCO.

\section{B. FFA (Free Fatty Acid)}

The FFA of the VCO can be seen in Figure 2. Statistical analysis showed overall fermentation time and concentration factor no significant effect on the FFA value of VCO produced (because $\alpha>0.05$ ). The combination of both factors fermentation time and concentration also no significant effect on the FFA value. The average value of FFA at $12: 53 \%$, this results corresponding quality standard ISO 7381: 2008 with a maximum value of $0.5 \%$ FFA content.

Increased levels of FFA can occur due to the hydrolysis process produces free fatty acids in the VCO. The hydrolysis process is affected by the water content in the oil and the activity of the lipase enzyme in oil.

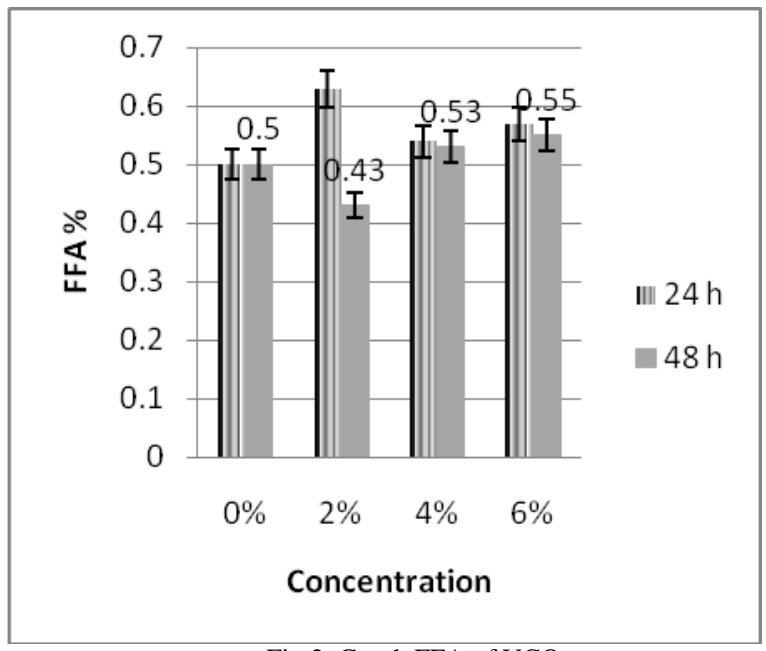

C. Density

Fig 2. Graph FFA of VCO

Statistical analysis Showed overall fermentation time and the concentration factor of no significant effect on the density value of VCO produced (Because of $\alpha>$ 0.05). The combination of both factors fermentation time and concentration Also no significant effect on the density value. The average of density values is $0.87 \mathrm{~g} / \mathrm{ml}$, these results are below the SNI 7381: 2008 quality standard with an average density of $0.915-0.920 \mathrm{~g} / \mathrm{ml}$. The density value can be affected by the presence of water or other components in VCO oil during the process of separating oil from coconut milk. The density of the VCO can be seen in Figure 3.

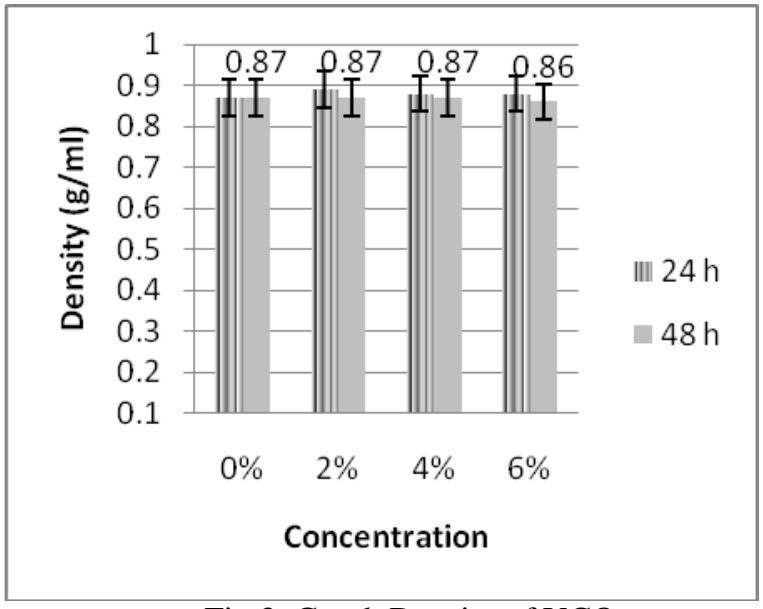

Fig 3. Graph Density of VCO

\section{CONCLUSION}

Based on the research results can be concluded that the combination of yeast fermentation time and concentration affect the yield VCO tempeh produced. The highest VCO yield was $31.47 \%$ using a $6 \%$ yeast concentration of 48 hours of fermentation. While the FFA values and density are not significantly different at each treatment.

\section{ACKNOWLEDGMENTS}

This research was supported by LPPM Universitas Veteran Bangun Nusantara Sukoharjo for internal researchers grants 2018 .

\section{REFERENCES}

[1] M. Asy'ari and B. Cahyono, "Pra-Standarisasi : Produksi dan Analisis Minyak Virgin Coconut Oil ( VCO ), ' JSKA, vol. IX, no. 3, pp. 1-9, 2006.

[2] M. Debmandal and S. Mandal, "Coconut (Cocos nucifera L .: Arecaceae): In Health Promotion and Disease Prevention," Asian Pac. J. Trop. Med., vol. 4, no. 3, pp. 241-247, 2011.

[3] Martini, S. A. Lindawati, A. A. Oka, I. A. Utami, and A. A. S. Kartini, "Peningkatan Teknik Pengolahan Buah Kelapa Menjadi Minyak Goreng Bermutu (Vco) Melalui Proses Fermentasi," UDAYANA MENGABDI, vol. 9, no. 2, pp. 108110, 2009.

[4] R. P. Maradesa, F. Fatimah, M. S. Sangi, and K. Kunci, "Kualitas Virgin Coconut Oil ( VCO ) Sebagai Minyak Goreng yang Dibuat dengan Metode Pengadukan dengan Adanya Penambahan Kemangi ( Ocimum sanctum L .)," vol. 3, no. 1, pp. 44-48, 2014.

[5] Ngatemin, Nurrahman, and J. T. Isworo, "Pengaruh Lama Fermentasi Pada Produksi Minyak Kelapa Murni (Virgin Coconut Oil) Terhadap Sifat Fisik, Kimia dan Organoleptik," J. Pangan dan Gizi, vol. 04, no. 08, pp. 9-18, 2013.

[6] P. Saikhwan, C. Nuchnet, W. Wanakayont, and A. Suksa-nga, "Extraction of Coconut Oil from Coconut Milk Foulants Using Enzyme," MATEC Web Conf., vol. 02008, no. 62, pp. 4-8, 2016.

[7] Y. Srivastava, A. D. Semwal, and A. Majumdar, "Quantitative and qualitative analysis of bioactive components present in virgin coconut oil Quantitative and qualitative analysis of bioactive," Cogent Food Agric., vol. 1, no. 1, 2016.

[8] R. Silaban and V. Hutapea, "Pembuatan Minyak Kelapa Murni ( Virgin Coconut Oil , Vco ) Melalui Kombinasi Teknik Fermentasi Dan Enzimatis Menggunakan Getah Pepaya,” pp. 55-64, 2012.

[9] A. M. Akinnuga, S. O. Jeje, O. Bamidele, and V. E. Sunday, "Dietary Consumption of Virgin Coconut Oil Ameliorates 
Lipid Profiles in Diabetic Rats," Physiol. J., vol. 2014, pp. 1015, 2014.

[10] M. A. Hamsi, F. Othman, S. Das, Y. Kamisah, K. Subermaniam, and K. Jaarin, "Effect Of Consumption Of Fresh And Heated Virgin Coconut Oil On The Blood Pressure And Inflammatory Biomarkers: An Experimental Study In Sprague Dawley Rats," Alexandria J. Med., vol. 51, no. 1, pp. 53-63, 2015.

[11] S. Winarti, Jariyah, and Y. Purnomo, "Proses Pembuatan VCO (Virgine Coconut Oil) Secara Enzimatis Menggunakan Papain Kasar VCO (Virgine Coconut Oil)," J. Teknol. Pertan., vol. 8, no. 2, pp. 136-141, 2007.

[12] P. V. Patty, "Pengaruh Lama Fermentasi Terhadap Ranciditas Minyak Kelapa Yang Diproduksi Secara Tradisional," Biopendix, vol. 1, no. 2, pp. 137-142, 2015.

[13] S. Sudarmadji, B. Haryono, and Suhardi, Analisa Bahan Makanan dan Pertanian. Yogyakarta: Liberty Yogyakarta, 2010.

[14] R. Moeksin, Y. Rahmawati, and P. Rini, "Metode Enzimatis , Sentrifugasi Dan Pemanasan," J. Tek. Kim., vol. 1, no. 15, pp. $11-14,2008$ 